\section{Commentary: When simple living-donor lobar transplantation is just not enough}

\author{
Konrad Hoetzenecker, MD, PhD
}

Scarcity of donor organs remains one of the main hurdles in contemporary lung transplantation. Western countries have addressed this problem by extending their cadaveric donor pool (eg, liberalization of donor criteria, promoting donation after circulatory death). Japanese transplant centers have for a long time fostered living-donor lobar lung transplantation (LDLLT). Excellent long-term results have been reported $^{1}$; however, the feasibility of LDLLT is mainly limited by restrictions in size-matching, and often only children or adults with an unusual small chest can be considered.

In this issue of the JTCVS Techniques, Nakajima and colleagues $^{2}$ summarize their institutional experience with extended techniques of LDLLT, namely native upper-lobe sparing LDLLT, right-to-left inverted LDLLT, and singlelobe LDLLT. ${ }^{2}$ All 3 techniques are based on a common consideration: to overcome size discrepancies between available donor lobe(s) and the recipient chest.

The Kyoto team has to be congratulated for once more taking the lead and improving the surgical technique of LDLLT. Both native upper-lobe sparing LDLLT and rightto-left inverted LDLLT require detailed anatomical knowledge and exceptional surgical skills. Adding complexity to an already complex procedure always bears a risk of increased complication rates. The authors red-flagged the risk of kinking the pulmonary artery anastomosis in their manuscript. In addition, due to the smaller diameters,

From the Division of Thoracic Surgery, Medical University of Vienna, Vienna, Austria.

Disclosures: The author reported no conflicts of interest.

The Journal policy requires editors and reviewers to disclose conflicts of interest and to decline handling or reviewing manuscripts for which they may have a conflict of interest. The editors and reviewers of this article have no conflicts of interest.

Received for publication July 27, 2020; revisions received July 27, 2020; accepted for publication July 31, 2020; available ahead of print Aug 12, 2020.

Address for reprints: Konrad Hoetzenecker, MD, PhD, Department of Thoracic Surgery, Medical University Vienna, Waehringer Guertel 18-20, 1090 Vienna, Austria (E-mail: konrad.hoetzenecker@meduniwien.ac.at).

JTCVS Techniques 2020;3:394-5

2666-2507

Copyright $(2020$ The Authors. Published by Elsevier Inc. on behalf of The American Association for Thoracic Surgery. This is an open access article under the CC BY-NCND license (http://creativecommons.org/licenses/by-nc-nd/4.0/).

https://doi.org/10.1016/j.xjtc.2020.07.036

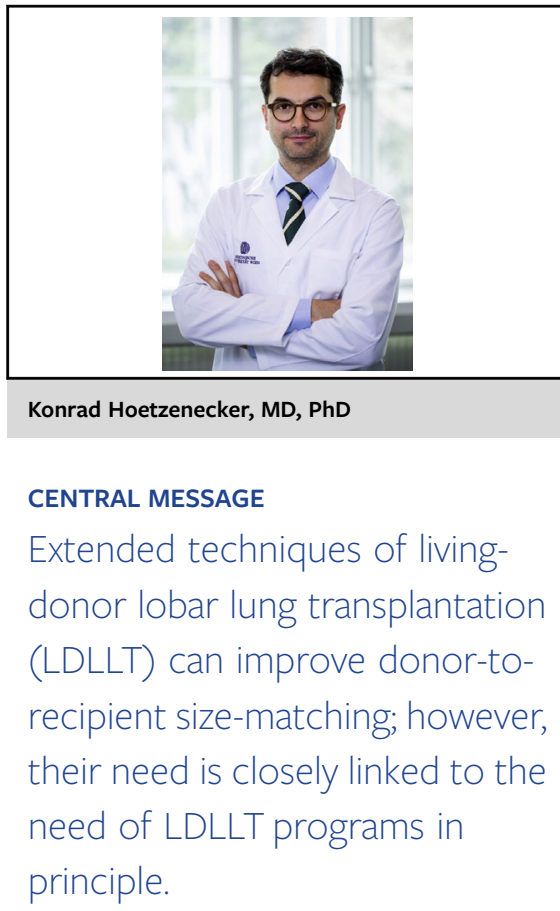

impaired healing is more relevant in lobar-to-lobar bronchial anastomosis than in lobar-to-main bronchus anastomosis. Finally, leaving a bronchial stump in immunosuppressed patients is risky even when buttressed with pericardium. It is impressive that despite the added complexity, extended LDLLT techniques had a low complication rate and a similar early post-transplant outcome as compared with standard LDLLT patients.

One main question arises: Are such extended techniques really necessary, or are there easier alternatives of providing patients with donor organs? Even today, a considerable number of lungs are still rejected due to presumably poor quality. We have previously shown that donor organs that had been rejected by up to 12 other centers within the Eurotransplant region could be transplanted with excellent long-term outcomes. ${ }^{3}$ A similar finding was published by Mulvihill and colleagues, ${ }^{4}$ analyzing United Network of Organ Sharing data. In addition, ex vivo lung perfusion is increasingly used as a platform to recondition primarily unacceptable organs: Edematous donor lungs can be perfused by high-oncotic solutions, ${ }^{5}$ organs with signs of pneumonia can be treated by high-dose antibiotis, ${ }^{6}$ and hepatitis $\mathrm{C}$ virus-positive grafts can be sterilized. ${ }^{7}$

Despite the aforementioned advances, organ availability remains suboptimal, especially for children and small adults with a retracted chest and blood group 0 . These patients should be routinely screened for a LDLLT as an 
alternative to cadaveric lobar lung transplantation. In addition, LDLLT and consequently extended LDLLT techniques are often the only option for transplant candidates from countries lacking an established organ donation system.

In summary, extended LDLLT is not just a technical finger exercise but could earn its place in LDLLT. However, its fate is closely related to the need of a LDLLT program in principle.

\section{References}

1. Nakajima D, Chen-Yoshikawa TF, Ohsumi A, Date H. Living-donor lobar lung transplants provide comparable pulmonary function to cadaveric lung transplants. J Thorac Cardiovasc Surg. August 28, 2019 [Epub ahead of print].
2. Nakajima D, Tanaka S, Ohsumi A, Date H. Outcomes of novel surgical procedures for graft size mismatch in living-donor lobar lung transplantation. J Thorac Cardiovasc Surg Tech. 2020;3:388-91.

3. Schwarz S, Muckenhuber M, Benazzo A, Glueck O, Evermann M, Beer L, et al Lung transplantation using donor lungs multiply declined for quality reasons. Presented at: 12th International Congress on Lung Transplantation; 2016; Paris.

4. Mulvihill MS, Lee HJ, Weber J, Choi AY, Cox ML, Yerokun BA, et al. Variability in donor organ offer acceptance and lung transplantation survival. J Heart Lung Transplant. 2020;39:353-62.

5. Nilsson T, Hansson C, Wallinder A, Malm CJ, Silverborn M, Ricksten SE, et al. Hemofiltration in ex vivo lung perfusion — a study in experimentally induced pulmonary edema. J Thorac Cardiovasc Surg. 2016;151:570-5.e1.

6. Nakajima D, Cypel M, Bonato R, Machuca TN, Iskender I, Hashimoto K, et al Ex vivo perfusion treatment of infection in human donor lungs. Am J Transplant. 2016;16:1229-37.

7. Galasso M, Feld JJ, Watanabe Y, Pipkin M, Summers C, Ali A, et al. Inactivating hepatitis $\mathrm{C}$ virus in donor lungs using light therapies during normothermic ex vivo lung perfusion. Nat Commun. 2019;10:481. 